Hans Schachl, Prof. Dr., Rector emeritus Private University College of Education, Linz, Austria

E-mail: hans.schachl@ph-linz.at

ORCID ID 0000-0001-7259-9444

\title{
CHALLENGE "STRESS" IN LEARNING AND PROFESSIONAL LIFE - RESULTS FROM BRAIN RESEARCH AND CONSEQUENCES
}

Abstract: Stressful events are very common in private and professional life, and above all, in schools. All in all it is essential for the whole life: In the brain the parts of Cognition are strongly influenced by the parts of Emotion. Stress not only leads to physical consequences, but also causes poorer performance in professional life and learning at school. Stress may also lead to rigid memories and the retrieval of habits rather than creative and complex solutions. Dangerous is also a possible weakening of the trust in self with the consequence of „Learned Helplessness“. Therefore: Anxiety and stress must be reduced. But it is also necessary to learn to cope with stress. For Stress Management is a combination of some of the following measures recommended: Instrumental management of stress, Mental management of stress and Regenerative management of stress.

Key words: Stress, Neurobiology of stress, stress consequences, stress management.

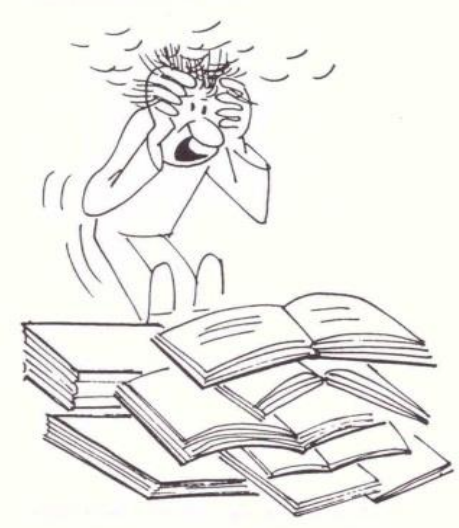

Leitner 1972

As we all know, stressful events are very common in private and professional life, and above all, in schools! Some people think, without pressure there is no achievement in professional work and pupils would not be motivated to learn. Obviously that is not true! Because we know a lot about stress-related disorders, and we also know, that stress can impair health and also cognitive functions and thereby lead to worse achievements!

Anxiety and stress cause negative feelings!

What do we know from brain research about emotions and feelings?

\section{The Role of Emotions:}

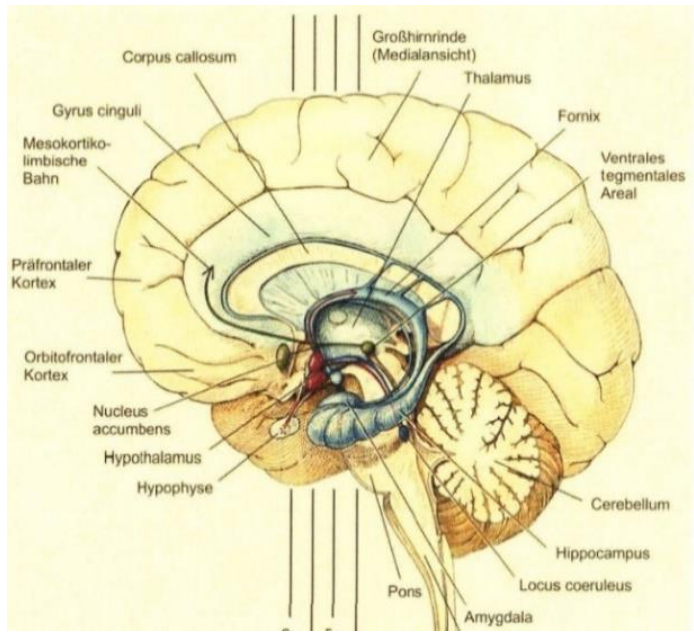

Essential for our life:

The parts of Cognition (Frontal Cortex, Hippocampus ...) are strongly influenced by the parts of Emotion (Limbic System with Amygdala, Rewarding System with Nucleus accumbens and Ventral Tegmental Area, Hypothalamus...)!

Förstl/Hautzinger/Roth, 2006, 5 
The Orbitofrontal Cortex is responsible for controlling of behaviour, for moral and ethics (Roth, 2011, 45). The Prefrontal Cortex is an important part of „working memory“ (Wang et al., 2011) and so also of intelligence. He is essential for introspection und metacognition too (Fleming et al., 2010). The Prefrontal Cortex is called the „highest leader in the brain“ or the „highest initiator“ (Kandel, 2012, 425f.), responsible for creativity, planning (dorsolateral part), making decisions and proper social behaviour (ventromedial part). Of utmost importance is the Hippocampus: this part is responsible for storing information into longterm memory, and also for retrieving (together with prefrontal cortex), but it's not the longterm memory itself. It's like a working memory (Roth, 2011, 109ff; Miller, 2008b; und Gelbard-Sagiv et al., 2008).

On the other hand: the Prefrontal Cortex is not only responsible for retrieving, but also for consolidating information (about 2-6 weeks after learning). Retrieving happens also in cooperation between prefrontal cortex and hippocampus.

A very clear message: If the hippocampus is damaged or doesn't work anymore, you can learn nothing new. It's the case for instance with Alzheimer's Disease: This people ask you in half an hour 10 times the same, because they cannot store the answers. They have a "moment to moment" consciousness. But the Hippocampus has a double function: he is also important for emotions (Roth, 2011, 110). That means, emotions have influence on storing and vice versa memory influences perception and retrieving of emotions. Entorhinal Cortex and Hippocampus interact for storing and retrieving of information. For that job electrical power with frequencies of $20-40 \mathrm{~Hz}$ (theta- and gamma-waves) are proved (Igarashi, 2014).

Additional tasks of Hippocampus:

The Hippocampus (especially the right posterior hippocampus) plays an important role with spatial navigation: this part increases with experience (experiment with taxi drivers in London). There is an impairment after a so called Transient Global Amnesia (Bartsch et al., 2010). The Hippocampus is also involved in planning of actions (Pastalkova et al., 2008). Parts of Prefrontal Cortex and of Hippocampus are involved in so called "Reinforcing- and Rewarding“"-processes, mediated by Dopamin (Luo, et al., 2011; Stuber et al., 2008).

The parts of Cognition (Frontal Cortex, Hippocampus ...) are strongly influenced by the parts of Emotion: The Amygdala (almond) is an emotional marker of the contents on their way to longterm memory and it has essential functions with anxiety, fear, joy! It plays a role in recognizing emotional signals in mimic expressions (Roth, 2011, 44, 324). The Mesolimbic System (Nucleus accumbens, Ventral Tegmental Area in the Pons, Substantia Nigra) is the central „Rewarding-System and Rewarding-Memory“ and also relevant for Motivation, Interest, etc. (Roth, 2011, 444f; Stuber et al., 2011). Therefore this System is very important for working and learning. The working chemicals are called „Endogene Opiods (Endorphins) und Dopamin (Rossato et al., 2009). Dopaminerg neurons fire with expected and unexpected rewards. But, if expected rewards occur not, the relevant chemical reaction also does not occur (Cohen et al., 2012, 85-88). Nucleus accumbens and Ventral Tegmental Area play an important role also in addiction (Lüscher, 2009) and in stress-induced depression (Lemos et al., 2012). The Hypothalamus plays an important role in vegetative processes, for the hormone system and also for the biology of the stress reaction.

Let's summarize:

1) Cognition and emotion are not separated, but they work together even in an anatomical structure and via chemical processes!

2) That means, without good emotions there is not good achievements, neither in business life nor in learning. 
In this context the focus should now set on the special topic ,stress“":

What is the current state of knowledge about stress? Stress developed in the evolution as an important survival program:

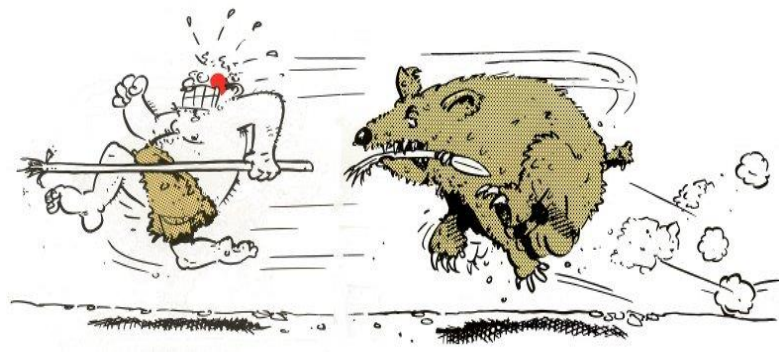

Necessary for survival (Kaluza, 2011, 16):

Activation of brain, heart (blood, oxygen), breathing, sweating, muscles, blood pressure, energy; of pain- and immune-tolerance, of blood-coagulation! Not necessary for survival in this situation, therefore reduction of

Schachl, 1991, 13/14 digestion, of saliva-production in the mouth; of libido.

Although the stress response is very complex, it can be focussed on two major stress systems:

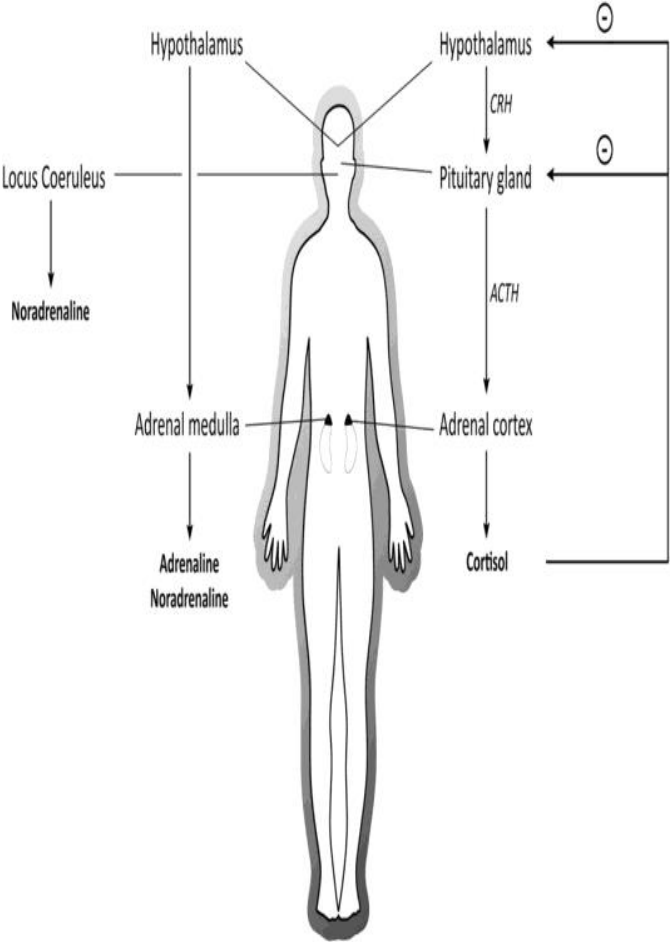
First: The rapid autonomous nervous system is activated within seconds to release catecholamines from the adrenal medulla and the locus coeruleus in the brain stem. Catecholamines (Adrenalin and Noradrenalin) are implicated in the 'fight-orflight' response (activation of circulation and breathing, but they also have profound effects on attention, working memory and long-term memory.

If after this first action the danger is over, the stress response will be finished!

If not, the second action starts: „Somewhat slower, the hypothalamus-pituitaryadrenal axis is activated, releasing corticotropinreleasing hormone (CRH) from the hypothalamus, which stimulates the anterior pituitary to secrete adrenocorticotropic hormone (ACTH). ACTH in turn causes the adrenal cortex to produce cortisol and release it into the blood stream.

Vogel/Schwabe, 2016

Cortisol reaches peak level concentrations $\sim 20-30$ min after stress onset and readily enters the brain to affect cognition and behaviour. Cortisol binds to two different receptors: The glucocorticoid receptor (GR) is expressed ubiquitously throughout the brain, whereas the mineralcorticoid receptor (MR) is mainly expressed in brain regions related to memory and emotion (Hippocampus, Amygdala, Prefrontal Cortex). On binding to these receptors, cortisol operates via two different modes of action, a non-genomic, often MR-mediated mode develops rapidly and enhances neural excitability in the Amygdala and Hippocampus, presumably supporting memory formation. This rapid mode is followed by a slower, often GR-dependent mode that is assumed to develop about $60-90 \mathrm{~min}$ after stressor onset and to involve longerlasting changes to DNA translation and transcription" (Vogel/Schwabe, 2016). Cortisol feedback to the pituitary, hypothalamus and other brain areas (e.g., the hippocampus) prevents the system from overshooting. Cortisol is released not only with stress, but in shifts during ,normal life“, with a peak after awakening (Roth-Strüber, 2015, 135). 


\section{Physical consequences of stress:}

The bodily consequences of stress are well-known: diseases of heart and circulation, of stomach and gut, problems with sexuality, weakening of immune-system, psychiatric disorders and so on. The interactions between the immune system and stress are an important field of research (Menard et al., 2017): On the one hand, chronic inflammations can lead to an increased sensitivity of the stress system with a weakening of the psychological resistance (resilience) up to psychiatric diseases, on the other hand stress leads to a weakening of the immune system with a higher susceptibility to disease (up to cancer).

An interesting finding (Sterley et al., 2018): Animal experiments have shown that the effects of stress from the stressed mice are also transmitted to the initially uninvolved animals, namely to the hypothalamus with $\mathrm{CRH}$ and also to the glutamate synapses. This is caused by an "alarm pheromone" that affects several other animals with the same stress changes. This "stress infection" is also quite plausible in the human domain!

A more fundamental way of "transmitting" stress is disturbing:

Even the stress sensitivity of mothers, caused by traumas (violence in partnership, abuse, great fear, etc.) in their own "past life", but especially also during pregnancy, can have a "transgenerational" effect. This means that epigenetic changes (in the methyl "switch molecules" of DNA) transfer the traumatic injuries and thus "sensitization" of the stress system from the mothers to the next generation(s) via the cortisol system (Youssef et al., 2018).

\section{What is ,Epigenetics“?}

Epigenetics comprises "a wide range of heritable changes in gene expression that occur in response to environmental influences and that do not result from alterations in the DNA sequence" (Hwang et al., 2017, 347). But what does this „epigenome language" look like?

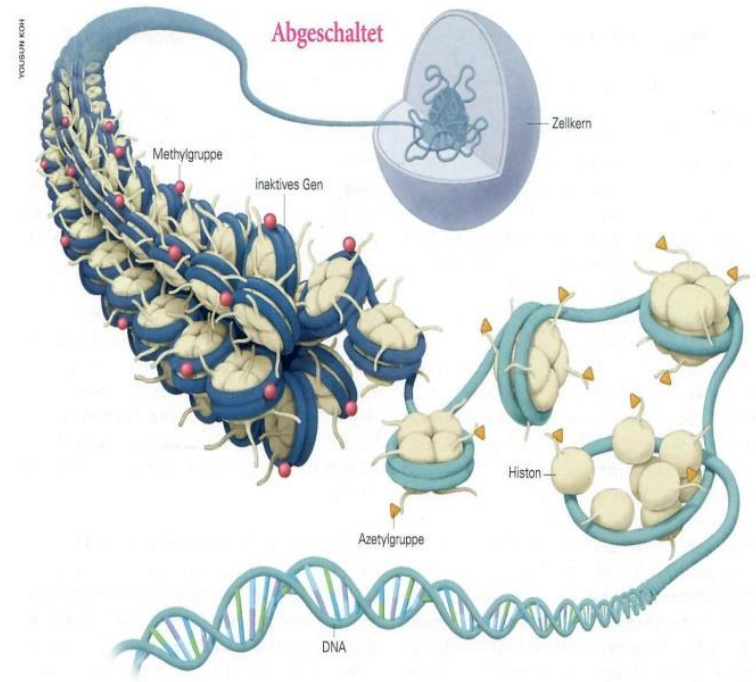

Gebhardt, 2018, 61 The DNA wraps around certain proteins, the histones. In this densely packed form, the DNA cannot be read, i.e. the genes are inactive here. The epigenetic "markings" influence the packing density and thus the accessibility of the genes:

Along the DNA thread, the bases (adenine, cytosine, guanine and thymine) are "loaded" with methyl groups (methylation; $\mathrm{CH}^{3}$ ) and thus made inaccessible for the reading process; the corresponding gene is thus switched off! Acetyl groups on the histones loosen the winding ("unpacking") and thus make the DNA "readable"; it is "switched on"!

In the representation of the human genome, the sites are then marked with these special molecules. In addition to the genetic code, the epigenome is thus obtained as the "second code". But a human being has many epigenomes (Epigenetik, 2013).

Genes are thus controlled by environmental influences that "switch the genes on and off", by methylation and acetylation, and also through other processes (chromatin remodeling e.g. synapse formation in early development, but also important in adult life; micro RNAs or "noncoding RNAs important for synapse formation and the growth of dendrites in early brain 
development). Epigenetic processes seem to be important for development and learning (FríasLasserre, Villagra \& Guerrero-Bosagna, 2018)!

Experiments with Animals: Early life stress (ELS) by maternal separation induced histone acetylations capable of modifying the expression of the genes Arc and Egr1 in their hippocampus (involved in synaptic plasticity), paralleled by raises in dendritic complexity and spine number of hippocampal CA3 pyramidal neurons. These events represent early steps in the adaption of neuronal networks to stressful environments, as they program the developing organism and influence the development of brain and behavior (Xie et al., 2013 in FríasLasserre, Villagra \& Guerrero-Bosagna, 2018).

In mice's early-life maltreatment due to abusive behavior by stressed caretakers that induces lasting DNA methylation changes in the brain-derived neurotrophic factor (BDNF) gene prompting its altered gene expression in the adult prefrontal cortex (Roth et al., 2009a in FríasLasserre, Villagra \& Guerrero-Bosagna, 2018).

Studies in mammals have demonstrated that epigenetic changes triggered by stress exposure can also be passed on to the offspring (Gapp et al., 2014 in Frías-Lasserre, Villagra \& Guerrero-Bosagna, 2018). It is important to highlight that while transgenerational effects derived from exposure of pregnant mothers affect the embryo, adult paternal exposures can produce transgenerational effects by potentially disrupting epigenetic processes during spermatogenesis (Rodgers et al., 2013, 2015; Milekic et al., 2015; Siklenka et al., 2015 in Frías-Lasserre, Villagra \& Guerrero-Bosagna, 2018).

Therefore, it is suggested that mammalian inheritance is highly prone to generate lasting epigenetic imprints driven by parental, prenatal and early-life stress, including malnutrition, trauma and maltreatment, leading to transgenerational consequences on neural mechanisms of cognition and emotion.

Experiments wih Humans: In humans it is difficult to study the inheritance of epigenetic alterations. The transgenerational study of the horrible environmental stress that induced PTSD in Holocaust victims, and its influences on following generations, allowed to demonstrate for the first time how a PTSD event can be inherited epigenetically in a transgenerational fashion in our own species. Yehuda et al., (2016, in Frías-Lasserre, Villagra \& Guerrero-Bosagna, 2018) studied a stress-related gene that has been associated with PTSD and depression (FKBP5), and demonstrated that people who suffered during the Holocaust presented DNA methylation modifications in this gene. This epigenetic influence was observed not only in exposed parents, but also in their offspring.

In this context, among these environmentally-induced emergent influences on cognitive development, socioeconomic disparities have also been documented: Children from poor socioeconomic backgrounds are more prone to mental illnesses, such as depression, than their peers from wealthier families, and are also more likely to present cognitive problems (Noble et al., 2015). These children from impoverished families presented increased DNA methylation at the serotonin transporter gene, which predicts higher threat-related amygdala reactivity. Importantly, the serotonin transporter gene drives a number of autonomic responses to stress (Feder et al., 2009 in Frías-Lasserre, Villagra \& Guerrero-Bosagna, 2018). These findings reveal that lower socioeconomic status acts as a stressor altering brain function. Thus, violent interpersonal treatment and unhealthy educational processes, such as bullying, or mistreatment from a teacher, can be classified as a repeated traumatizing stimuli capable of leading to PTSD (Foa et al., 2009 in Frías-Lasserre, Villagra \& Guerrero-Bosagna, 2018), with cultural as well potentially epigenetic inheritance effects. 
A very important question: Is there a „reversibility“ of epigenetic changes? Considering current epigenetic research, it is possible to support the idea that epigeneticallyinduced modifications may regulate how an organism adjusts to changes in the environment, making it less reliant on structural DNA.

Therefore, epigenetic changes "may not only change for the worse, but with the right intervention, also for the better" as recently stated by (Mulder et al., 2017 in Frías-Lasserre, Villagra \& Guerrero-Bosagna, 2018).

\section{Relevance of Neurobiological Epigenetics in Education:}

Early life experiences have been highlighted as key environmental regulators of epigenetic processes in human biology including psychological and cognitive development (Hollar, 2016a in Frías-Lasserre, Villagra \& Guerrero-Bosagna, 2018). A recent review by David Denhardt (2017, in Frías-Lasserre, Villagra \& Guerrero-Bosagna, 2018) points out that economic deprivation, drug abuse and stressful social interactions (such as social defeat and parental abuse, or maltreatment by a caregiver) have different impacts on cognitive processes and psychological stability, which are mediated by epigenetic processes (see also Roth et al., 2009a; Turecki and Meaney, 2016; Denhardt, 2017 in Frías-Lasserre, Villagra \& Guerrero-Bosagna, 2018).

Epigenetics Within the Classroom: Studies suggest that epigenetic mechanisms are linked to learning and memory. For instance, DNA methylation and histone post-translational changes (methylation and acetylation) are capable of editing gene function or influencing interactions between the genome and core histones. These epigenetic modifications lead to chromatin remodeling, which ultimately defines transcriptional patterns in a variety of genes involved in memory formation and learning (Kim and Kaang, 2017 in Frías-Lasserre, Villagra \& GuerreroBosagna, 2018). Based on current evidence from epigenetic studies, these stress factors and unhealthy environments may alter the formation of neural circuits, affecting the acquisition of abilities linked to learning.

In addition: It has been demonstrated that the occupational stress observed in teachers is linked to the physiological stress regulation of students (Oberle and Schonert-Reichl, 2016 in Frías-Lasserre, Villagra \& Guerrero-Bosagna, 2018).

Increased activation of a gene (NR4A1), which is actually important for neuroplasticity, can have an effect on the energy supply of the nerve cells (through the mitochondria in the cells) due to chronic stress. The result can be synaptic loss and cognitive impairment (Jeannetau et al., 2018). Cognitive damage can therefore occur! So the question arises: How does stress affect learning and memory, important not only for education, but also for working in business, especially in life-long learning? Let's look into the brain: Based and in addition to the epigenetic changes there are important effects of stress on learning and

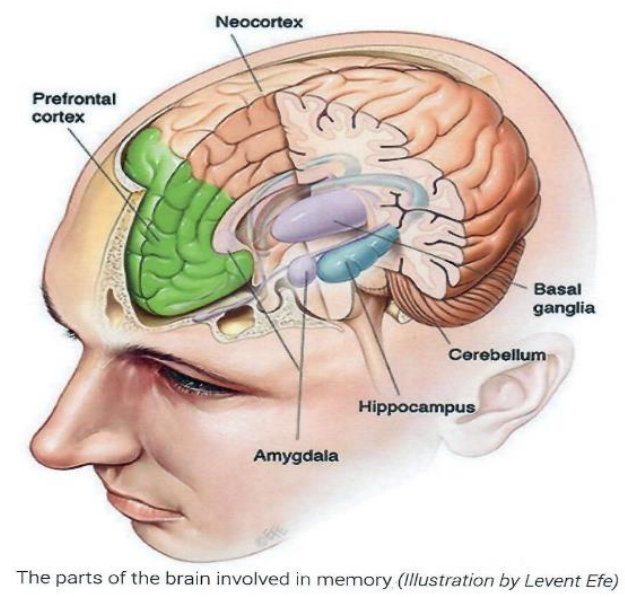

memory (Vogel/Schwabe, 2016):

https://www.google.com/search?q=hippocampus+prefrontal+cortex+connection\&ie=utf- $8 \&$ oe=utf$8 \& c l i e n t=$ firefox-b

The integration of new information into existing knowledge is fundamental for learning and for the whole life too. Prior knowledge, represented as a schema, facilitates memory encoding. For this schema-related learning one need the medial prefrontal cortex (mPFC), that

Neuroscience

Materials of International Practical Internet Conference "Challenges of Science" 
rapidly integrates new information into the schema, whereas schema-incongruent or novel information is encoded by the hippocampus.

Stress is a powerful modulator of prefrontal and hippocampal functioning and first studies suggest a stress-induced deficit of schema-related learning. Stress affects the neural ensemble underlying the efficient use of schemas during learning (Vogel et al., 2018). Stress impairs memory-,,updating"! Relevant for it is the Cortisol-activity in the Amygdala.

Some results indicate, that the presence of stress impairs the ability to access consolidated autobiographical memories; moreover, although stress has no effect on memory recollection, stress alters how recollected experiences are reconsolidated back into memory traces (Sheldon et al., 2018). Stress just before a retrieval-process (with high level of Noradrenalin and Adrenalin, but not elevated Cortisol) impairs the recall of information; see stress before exams! The recall deficit was found already with children at the age of 8-10 years (Vogel/Schwabe, 2016)!

Interestingly: Stress just before encoding, after presentation of new information, and consolidation enhances memory building, probably because of enhancing attentional processes by Noradrenalin and Adrenalin, especially for emotionally arousing material.

There is a dependence on emotion and on context too: In sum, being moderately stressed can enhance memory formation for emotional material and information that is related to the stressful context, whereas stress may impair the encoding of stressor-unrelated material. The different effects of stress on memory depend on interactions between Noradrenalin and Cortisol in the Amygdala and are thus often stronger for emotional learning materials (Vogel/Schwabe, 2016).

The hippocampus is very vulnerable (maybe because of a bigger number of Cortisolreceptors; Suzuki/Fitzpatrick, 2016, 239) to severe and prolonged stress (Rahman, et al, 2016): Reduction of hippocampal volume was found, because of loss of dendritic spines and less neurogenesis (Egeland/Zunszain/Pariante, 2015; Ewen, 2016), and also because of reduced glial volume and numbers. BDNF (brain derived neurotrophic factor), very important for neuronal growth and plasticity, is also reduced with chronic stress.

Stress affects negatively important proteins like CREB (Sardari et al., 2015). This is also important, because a high level of CRF impairs motivation, decision processing (Bryce/Floresco, 2016) and working memory in Prefrontal Cortex (Hupalo/Berridge, 2016).

All these impairments lead to poorer performing in learning and professional tasks and, for instance, to deficits in spatial memory! A ,antidote“ is Oxytocin (Jurek, 2015), because of its benefit on CRF (this is a „main regulator of stress response"). That means, positive social relations (associated with Oxytocin) are helpful for coping with stress!

Furtheron it was shown, that ,stress induces a qualitative shift in the systems guiding learning (and, most likely, retrieval), from a cognitive, hippocampus-dependent memory system towards a habit-like memory system based on striatum" (Vogel/Schwabe, 2016).

In sum: „Prolonged or chronic activation of the HPA axis has been consistently associated with neuronal loss, decreased neurogenesis and altered neural connectivity and ... stress exposure has also been strongly linked to alterations in epigenetic markers that may ultimately lead to changes in gene expression. ...And these epigenetic mechanism could play a role in the pathogenesis of neurodegenerative disorders including Alzheimer Desease" (Cordner/Tamashiro, 2016). Repeated, chronic stress has negative impact on nerve cells: dendrites shrink, the spine (docking station for other nerve cells) density in hippocampus and prefrontal cortex is reduced. These processes are reversibel to some extent, especially in young animals and humans; physical exercise has a positive influence (Ewen, 2016)! 
New research (Morena et al., 2016; Di et al., 2016) has shown, that the EndocannabinoidSystem plays an important role with stress, because it affects the Hypothalamus-PituitaryAdrenal-Axis: it can be attenuating, but also anxiety enhancing. Chronic stress can modify this system. In this context it must be discussed the use of Cannabis with positive and negative effects (Haney and Evins, 2016; Ramaekers et al., 2016; Fedota, 2016; Sutherland et al., 2016)!

As a summary:

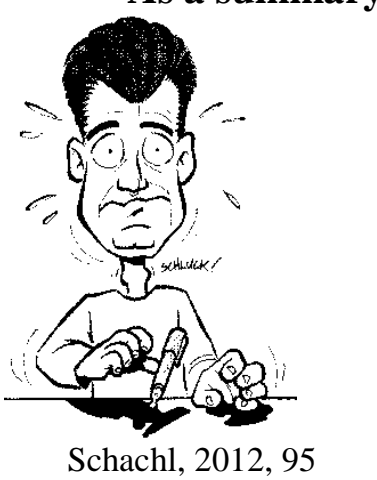

Stress in learning, teaching and in professional life has very important consequences: On the hand emotions and light stress (challenges, unexpected and new information) have positive effects in memory formation.

But on the other hand: Stress, especially anxiety leads to stronger storing of negative events (bad exams and professional events, interpersonal conflicts with parents, teachers, peers, chiefs, colleagues) with enduring frustration and negative attitude towards school, learning, companies, and to less motivation for life long learning).

And finally, stress may lead to rigid memories and the retrieval of habits rather than creative and complex solutions (Vogel/Schwabe, 2016). Dangerous is also a possible weakening of the trust in self with the consequence of „Learned Helplessness“" (Seligman, 1979). In animal studies could be shown, that helplessness leads to lower activation in many brain areas, like prefrontal cortex, reward-processing regions, amygdala and hippocampus (Kim et al., 2016). Therefore it is clear, that helplessness is combined wich lower learning and memory achievement. Often the learner's abilities are underestimated because their full achievement can not be reached: stress before exams impairs recalling the knowledge.

The effects of stress follow an ,inverted U-shape“-curve (Ewen, 2016), that means, higher levels of stress and prolonged stress are impairing! This is in accordance with the old ,YYrkes-DodsonLaw“ (1908): http://changingminds.org/explanations/motivation/yerkes-dodson.htm

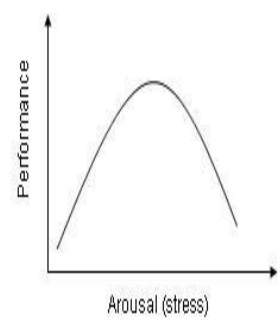

This law is an empirical relationship between arousal and performance, which was developed by Yerkes and Dodson 1908 in animal studies. It means, that performance increases with arousal, but after a medial level there is a decrease!

Further research and practical observation found, that in humans there are individual differences and dependences on tasks too: For simple tasks more arousal is needed, for difficult and complex tasks less arousal (more relaxation) is needed!

\section{A special topic: Stress and creative problem solving}

Stress hinders creativity and problem solving. Stress creates thought blockades like a board in front of the head. The reaction is then often a "return" to "old habits" instead of trying to find new, good solutions: $\mathrm{It}^{\star} \mathrm{s}$ like ,flipping the brain from reflective to reflexive control of behavior“ (Arnsten, 2015).This can create a „Devil's Circle“: stress hinders finding good solutions, and this in turn frustrates and creates new stress.

Stress is a big problem in education: So report nearly $70 \%$ of primary school children (Valizadeh et al. in Vogel/Schwabe, 2016) symptoms such as worries, anxiety or sadness, and many teachers complain about to much stress.

Therefore: What must be done against anxiety and stress in schools, and also in adult's life? First of all: Anxiety and stress must be reduced! 
For that: Teachers, parents and students, persons involved in business must be informed and be aware of the effects of stress on learning, working and life. And second: We must learn to cope with stress!

To the topic , reduction of anxiety and stress": The guiding principle is to learn (and also teach and live) with joy! Teachers must give interesting lessons, which are understandable and they have to underpin the learning process. And above all, teaching must make students curious. The teachers must be enthusiastic themselves! Persons in business life should also try to find jobs and activities, which they like. Joy must not be every day, but it should be a workable basis.

You remember: Our life on the whole, learning, professional performance, private satisfaction is mainly dominated by areas of emotions, by the Limbic System. Most of the processes are unconscious. To influence these processes we must focus on good relationship, empathy, trust, positive reinforcement. And we must avoid aggressive, anxiety-causing behavior. A good guiding principle: Make humans strong and clarify the facts!

But even though best chiefs, colleagues, best working conditions, good private partners, good teachers with best lessons, anxiety and stress remain! Therefore „coping“6 (stress management) ist necessary! Whether something/someone makes stress or not, depends on the personal appraisal. The individual appraisal of possible stressful events and stressors and also available methods of coping determine, whether the biological reactions occur and impair. Because of „subjectivity“ (genetics, prior experiences) there are different reactions on stress and people need different coping-strategies.

\section{Stress Management:}

To recommend is a combination of some of the following measures:

Instrumental management of stress

Mental management of stress

Regenerative management of stress

Instrumental management of stress: Pupils in schools need competencies in the subjects they have to learn (that means, they must learn to learn); and in business life people must also improve their abilities. Total in life social competencies (mutual supporting etc.) are fundamentally important. Andy for managing private life, business and learning are self management competencies necessary: planning, organizing, preparation for exams in time, establishing a good working place, ...). Very important, but the most diffficult one is Mental management of stress:

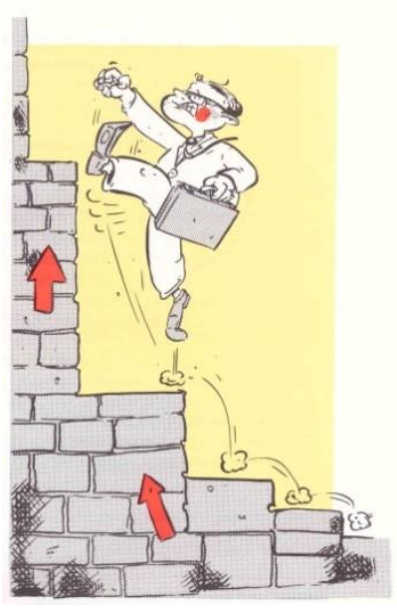

Schachl, 1991, 23
Accepting the reality, self control (accepting the own limits, ...): are the steps to high? Is the planned professional career attainable? Critical analysis of the own appraisals:

Am I really a loser? Prior to this judgement, all achievements must be assessed, not only the deficits.

„Change of thinking“ (exams and professional tasks as challenges, not as threats).

Self ,affirmations“ (I will succed, I am well prepared, ...)

Important for teachers:

Teaching should be more focused on strenghts than on weaknesses!

Regenerative management of stress: Enjoy the different types of relaxation! 
There are also special techniques like Yoga, Meditation, Autogen Training, Jacobson's „Progressive Muscle Relaxation“. Some remarks to the Jacobson-technique „Progressive Muscle Relaxation" (Jacobson, 1959): It is very easy and works well to come down from high-levelstress! The basic procedure: Strain - hold this tension - relax! An example: clench your right or left fist and hold this tension for five to seven seconds. Then relax by opening your fist. It is important that you consciously enjoy this relaxation. Repeat this exercise. "Work" the muscles from head to toe according to this pattern (tensing - holding - relaxing).

This technique can be combined with ,positive affirmations“: I feel good, I am relaxed, I don't have stress, ...

Focusing on good breathing makes sense too: "Attention to breath-meditation" has positive impacts on regulating aversive emotions, by down-regulating activation of amygdala (Doll et al., 2016).

Meditation has also positive effects (Ricard et al., 2015; Gothe et al., 2013) depending on the kind of meditation: „Concentration-meditation“ acitvates frontal brain areas, „Carefulnessmeditation“ areas in the parietal and temporal lobes; and „Empathy-meditation“ has impacts on regions between Parietal- and Temporal lobes, and on Medial Prefrontal Cortex and Insula.

During meditation „neuronal oscillations“ occur, that means, synchronous electrical impulses. On particular Gamma-waves (frequency $40 \mathrm{~Hz}$ ) are interesting, because they are related to higher cognitive functions and consciousness. A research with Tibetian monks, who meditated a long time very intensively, revealed the most intensive Gamma-waves, which ever were observed with humans (Suzuki/Fitzpatrick, 2016, 348ff.).

Other studies (with MRI) showed a surprising result (Suzuki/Fitzpatrick, 2016, 354ff.): During meditation less activity in frontal areas. Surprising but nevertheless logic: because of a better control of attention less work was necessary. It fits to the „Theory of transient hypofrontality“" (Dietrich; Schneider in Landrichinger, 2015, 34).

Another finding: With meditation inflammation marker decreased; and the activity of Telomerase (important with aging) increased.Very helpful are Music, Fine Arts, and Physical Exercises!

Now to a very special and important topic, the positive effects of physical exercise: From evolutionary and also ontogenetic history physical exercise is a natural basic need. And it is very important for cognitive learning too!

For that topic the headlines: Physical exercise is important for health of the whole body: muscles, circulation, breathing, immune system, and so on. But it works positively also for the brain, therefore for mental health and for thinking and learning too:

Multisensoric Integration, increasing of attention, positive impact on synapses and on neurogenesis, reduction of Cortisol, therefore reduction of stress. Positive impact on ,chemistry of soul": Stimulation of Dopamin, Endorphines and Endocannabinoids cause better emotions.

Positive impact on behavior (also of school pupils). For learning and working very important is the effect of exercise on attention: Attention is higher, if the lessons, working hours are interrupted by breaks with exercise (Dordel/Breithecker in Leitner/Kainberger, 2015, 22; and Möller et al., 2016). In schools this result must lead to a change of thinking about the traditional „frontal teaching"'!

At the end of the topic „Stress“: Stress has enormous consequences on our ability to learn, to perform, to think. First of all we have to do intensive work for reducing unnecessary and sometimes really silly stressful events. And we must learn to cope with anxiety and stress! This is helpful for success in learning, for career, satisfying business and private life, and above all, for physical and mental health. 


\section{Literature}

1. Arnsten, A. F. T. (2015). Stress weakens prefrontal networks: molecular insults to higher cognition. In: Nature Neuroscience, 18, 1376-1385.

2. Bartsch, T., Schönfeld, R.; Müller, F. J.; Alfke, K.; Leplow, B.; Aldenhoff, J.; Deuschl, G. \& Koch, J. M. (2010). Focal Lesions of Human Hippocampal CA1 Neurons in Transient Global Amnesia Impair Place Memory. In: Science, 11. June 2010, 1412-1415.

3. Beck, F. (2014). Sport macht schlau: Mit Hirnforschung zu geistiger und sportlicher Höchstleistung. Wien: Goldegg Verlag.

4. Beck, H.; Anastasiadou, S.; Meyer zu Reckendorf, C. (2016). Faszinierendes Gehirn. Eine bebilderte Reise in die Welt der Nervenzellen. Heidelberg: Springer.

5. Borgstedt, N. (2015). Aerobe und anaerobe Ausdauer. In: http://www.netzathleten.de/gesundheit/lexikon/40-aerobe-und-anaerobe-ausdauer (16.08.2015).

6. Bryce, C. A.; Floresco, S. B. (2016). Perturbations in Effort-Related Decision-Making Driven by Acute Stress and Corticotropin-Releasing Factor. In: Neuropsychopharmacology, 41, 2147-2159, 24. Feb.

7. Chaddock, L., Erickson, K. I., Praksh, R. S., Voss, M. V., VanPatter, M., Pontifex, M. B. et al. (2012). A Functional MRI Investigation of the Association Between Childhood Aerobic Fitness and Neurocognitive Control. In: Biol Psychol, 89, 260-268.

8. Cohen, J. Y.; Haesler, S.; Vong, L.; Lowell, B. B. \& Uchida, N. (2012). Neuron-type-specific signals for reward and punishment in the ventral tegmental area. In Nature, 2. February 2012, 85-88.

9. Cordner, Z. A.; Tamashiro, K. L. K. (2016). Effects of chronic variable stress on cognition and Bace1 expression among wild-type mice. In: Translational Psychiatry, 6, doi: 10.1038/tp.2016.127, 12. July.

10. Di, S. Itoga, C. A.; Fisher, M. O.; Solomonow, J.; Roltsch, E. A.; Gilpin, N. W. \& Tasker, J. G. (2016). Acute Stress Suppresses Synaptic Inhibition and Increases Anxiety via Endocannabinoid Release in the Basolateral Amygdala. In: The Journal of Neuroscience, 10. August, doi: 10.1523/JNEUROSCI.227915.2016.

11. Doll, A. Hölzel, B. K.; Mulej Bratec, S.; Boucard, C. C.; Xie, X.; Wohlschläger, A. M. \& Sorg C. (2016). Mindful attention to breath regulates emotions via increased amygdala-prefrontal cortex connectivity. In: NeuroImage, Vol. 134, 305-313.

12. Egeland, M.; Zunszain, P. A.; Pariante, C. M. (2015). Molecular mechanisms in the regulation of adult neurogenesis during stress. In: Nature Reviews Neuroscience, 16, 189-200.

13. Epigenetik (2013). In: Planet Wissen. www.planetwissen.de/natur_technik/forschungszweige/epigenetik/index.jsp.

14. Ewen, B. S. (2016). Stress-induced remodeling of hippocampal CA3 pyramidal neurons. In: Brain Research, 1645, 50-54.

15. Fedota, J. R. (2016). Insula Demonstrates a Non-Linear Response to Varying Demand for Cognitive Control and Weaker Resting Connectivity With the Executive Control Network in Smokers. In: Neuropsychopharmacology 41, 2557-2565.

16. Firth, J.; Stubbs, B.; Vancampfort, D.; Schuch, F.; Lagopoulos, J.; Rosenbaum, S.; Ward, P. B. (2018). Effect of aerobic exercise on hippocampal volume in humans: A systematic review and meta-analysis. In: NeuroImage, Vol. 166, 1. February, 230-238.

17. Fleming, S. M.; Weil, R. S.; Nagy, Z.; Dolan, R. J. \& Rees, G. (2010). Relating Introspective Accuracy to Individual Differences in Brain Structure. In: Science, 17. September, 1541-1543.

18. Förstl, H.; Hautzinger, M.; Roth, G. (2006): Neurobiologie psychischer Störungen. Springer Medizin Verlag, Heidelberg.

19. Frías-Lasserre, D.; Villagra, C. A. \& Guerrero-Bosagna, C. (2018). Stress in the Educational System as a Potential Source of Epigenetic Influences on Children's Development and Behavior. In: Front. Behav. Neurosci., 13 July 2018 | https://doi.org/10.3389/fnbeh.2018.00143.

20. Gebhardt, U. (2018). Geerbte Erfahrungen. In: Gehirn\&Geist, 01, 58-63.

21. Gelbard-Sagiv, H.; Mukamel, R.; Harel, M.; Malach, R. \& Fried, I. (2008). Internally Generated Reactivation of Single Neurons in Human Hippocampus During Free Recall. In Science, 2008, 96-100.

22. Gothe, N., Pontifex, M. B., Hillman, C., \& McAuley, E. (2013). The Acute Effects of Yoga on Executive Function. In: Journal of Physical Activity \& Health, 10 (4), 488-495.

23. Haney, M.; Evins, A. E. (2016). Does Cannabis Cause, Exacerbate or Ameliorate Psychiatric Disorders? An Oversimplified Debate Discussed. In: Neuropsychopharmacology Reviews, 41, 393-401. 
24. Hupalo, S.; Berridge C. W. (2016). Working Memory Impairing Actions of Corticotropin-Releasing Factor (CRF) Neurotransmission in the Prefrontal Cortex. In: Neuropsychopharmacology, doi: 10.1038/npp.2016.85, 8. June.

25. Hwang, J-Y.; Aromolaran, K. A.; Zukin, R. S. (2017). The emerging field of epigenetics in neurodegeneration and neuroprotection. In: Nature Reviews Neuroscience, 18, 347-361.

26. Igarashi, K. M.; Lu, L.; Colgin L. L.; Moser M. B. \& Moser E. I. (2014). Coordination of entorhinalhippocampal ensemble activity during associative learning. In: Nature, 13162, 16. April 2014.

27. Jacobson, E. (1959). Progressive Relaxation. A physiological and clinical investigation of muscular states and their significance in Psychology and Medical Practice. 2. Aufl., Chicago: The University of Chicago Press.

28. Jeanneteau, F.; Barrère, C.; Vos, M.; De Vries, C. J. M.; Rouillard, C.; Levesque, D.; Dromard, Y.; Moisan, M-P.; Duric, V.; Franklin, T. C.; Duman, R. S.; Lewis, D. A.; Ginsberg, S. D. \& Arango- Lievano, M. (2018). The Stress-Induced Transcription Factor NR4A1 Adjusts Mitochondrial Function and Synapse Number in Prefrontal Cortex. In: Journal of Neuroscience, 38 (6) 1335-1350, 7. February 2018.

29. Jurek, B.; Slattery, D. A.; Hiraoka, Y.; Liu, Y.; Nishimori, K.; Aguilera, G.; Neumann, I. D. \& van den Burg, E. H. 2015). Oxytocin Regulates Stress-Induced Crf Gene Transcription through CREB-Regulated Transcription Coactivator 3. In: The Journal of Neuroscience, 2. Sept., 35 (35), 12248-12260.

30. Kaluza, G. (2011): Stressbewältigung. Trainingsmanual zur psychologischen Gesundheitsförderung. 2. Aufl., Heidelberg: Springer.

31. Kandel, E. R. (2006). In Search of Memory. The Emergence of a New Science of Mind. New York: Norton.

32. Kandel, E. R. (2012). Das Zeitalter der Erkenntnis. Die Erforschung des Unbewussten in Kunst, Geist und Gehirn von der Wiener Moderne bis heute. München: Siedler.

33. Kassymova, G. K.; Schachl, H. (2017). What do we know about stress and education? In: MATERIALS of the International scientific-practical conference on the theme «Modern trends of moral and spiritual education and socialization of young generation» in the context of the program article of the President of the RK N.Nazarbayev «Course towards the future: modernization of Kazakhstan's identity»; volume 2, Kazakhstan: Taraz, 28 March 2018; p. 310-313.

34. Kassymova, G. K.; Schachl, H.; Sangilbayev, S. (2018). Enhancing students' concentration on lesson in stress situation. In: Materials of The First International Scientific and Practical Internet Conference "Science and Education in the $21^{\text {st }}$ Century, February 17-18, Astana: Public Fond „Bridges of Consent.

35. Kassymova G. K.; Sangilbayev, O. S.; Schachl, H. (2018). Methods of Coping with stress in the education system. In: Bulletin of Kazakh National Pedagogical University after Abai, Series of Psychology, №1 (54), 133-139.

36. Kim, Y.; Perova, Z.; Mirrione, M. M.; Pradhan, K.; Henn, F.A.; Shea, S.; Osten, P. \& Li, B. (2016). Whole-Brain Mapping of Neuronal Activity in the Learned Helplessness Model of Depression. In: Front. Neural Circuits, http://dx.doi.org/10.3389/fncir.2016.00003, 3. February.

37. Landrichinger, T. (2015). Die Implementierung der „Bewegten Schule“ als Instrument und systemischer Ansatz der kontinuierlichen Schul- und Unterrichtsentwicklung in der Sekundarstufe 1 in Oberösterreich. Bedeutung der Schulleitungen und der Schulaufsicht in Bezug auf Rahmenbedingungen, Vorgehensweise, Strukturen und Entscheidungsprozesse. Master Thesis an der Donau Universität Krems.

38. Langdon, K. D. \& Corbett, D. (2011). Improved Working Memory Following Novel Combinations of Physical and Cognitive Activity. In: http://nnr.sagepub.com/content/26/5/523.short (16.08.2015).

39. Leitner, S. (1972) So lernt man lernen. Freiburg, Herder-Verlag.

40. Leitner, M.; Kainberger, S. (2015). Lernen braucht eine Bewegte Schule! In: Bewegung \&Sport, 1, 21-24.

41. Lemos, J. C.; Wanat, M. J.; Smith, J. S.; Reyes, B. A.; Hollon, N. G.; Van Bockstaele, E. J.; Chavkin, C. \& Phillips, P. E. (2012). Severe stress switches CRF action in the nucleus accumbens from appetitive to aversive. In: Nature, 18. October 2012, 402-406.

42. Luo, A. H.; Tahsili-Fahadan, P.; Wise, R. A.; Lupica, C. R. \& Aston-Jones, G. (2011). Linking Context with Reward: A Functional Circuit from Hippocampal CA3 to Ventral Tegemental Area. In: Science, 15. July 2011, 353-356.

43. Lüscher, C. (2009). Die Suchtfalle. In: Gehirn\&Geist, 12, 48-52.

44. Menard, C.; Pfau, M. L.; Hodes, G. E. \& Russo, S. J. (2017). Immune and Neuroendocrine Mechanisms of Stress Vulnerability and Resilience. In: Neuropsychopharmacology, 42, 62-80.

45. Miller, G. (2008). Hippocampal Firing Patterns Linked to Memory Recall. In: Science, 5. Sept., 1280-1281.

46. Morena, M.; Patel, S.; Bains, J. S. \& Hill, M. N. (2016). Neurobiological Interactions Between Stress and the Endocannabinoid System. In: Neuropsychopharmacology Reviews, 41, 80-102.

Neuroscience

Materials of International Practical Internet Conference

"Challenges of Science" 
47. Möller, K.; Cress, U.; Huber, S. (2016). Mathe mit der Matte. In: https://www.iwmtuebingen.de/www/de/forschung/projekte/projekt.html?name=VerkoerperlichtesLernenNumerositaet\&disp name=Mathe\%20mit\%20der\%20Matte.

48. Noble, K. G.; Houston, S. M.; Brito, N. H.; Bartsch, H.; kann, E.; Kuperman, J. M.; Akshoomoff, N.; Amaral, D. G.; Bloss, C. S.; Libiger. O.; Schork, N. J.; Murray, S. S.; Casey B. J.; Chang, L.; Ernst, T. M.; Frazier, J. A.; Gruen, J. R.; Kennedy, D. N.; Van Zijl, P.; Mostofsky, S.; Kaufmann, W. E.; Kenet, T.; Dale, A. M.; Jernigan, T. L. \& Sowell, E. R. (2015). Family income, parental education and brain structure in children and adolescents. In: Nature Neuroscience, 18, 773-778.

49. Pastalkova, E.; Itskov, V.; Amarasingham, A. \& Buzsáki, G. (2008). Internally Generated Cell Assembly Sequences in the Rat Hippocampus. In: Science, 2008, 5. September, S. 1322ff.

50. Perini, R.; Bortoletto, M.; Capogrosso, M.; Fertonani, A. \& Miniussi, C. (2016). Acute effects of aerobic exercise promote learning. In: Scientific Reports 6, doi: 10.1038/srep 25440, 5. May.

51. Rahman, M. M.; Callaghan, C. K.; Kerskens, C. M.; Chattarji, S. \& O'Mara, S. M. (2016). Early hippocampal volume loss as a marker of eventual memory deficits caused by repeated stress. In: Scientific Reports 6, doi: 10.1038/srep29127, 4. July.

52. Ramaekers, J. G.; van Wel, J. H.; Spronk, D. B; Toennes, S. W.; Kuypers, K. P. C.; Theunissen, E. L. \& Verkes, R. J. (2016). Cannabis and tolerance: acute drug impairment as a function of cannabis use history. In: Scientific Reports 6, 26843.

53. Ratey, J. J.; Hagerman, E. (2013). Superfaktor Bewegung. Das Beste für Ihr Gehirn! Kirchzarten bei Freiburg: VAK Verlag.

54. Ricard, M.; Lutz, A.; Davidson, R. J. (2015). Drei Wege zum Nirwana. In: Gehirn\&Geist, 5, 40-46.

55. Rogge, A-K.; Röder, B.; Zech, A. \& Hötting, K. (2018). Exercise-induced neuroplasticity: Balance training increases cortical thickness in visual and vestibular cortical regions In: NeuroImage, Volume 179, 471-479, 1. October 2018.

56. Rossato, J. I.; Bevilaqua, L. R.; Izquierdo, I.; Medina, J. H. \& Cammarota M. (2009). Dopamine Controls Persistance of Long-Term Memory Storage. In: Science, 21. Aug., 1017-1020.

57. Roth, G. (2011). Bildung braucht Persönlichkeit. Wie Lernen gelingt. Stuttgart: Klett-Cotta.

58. Roth, G.; Strüber, N. (2015). Wie das Gehirn die Seele macht. Stuttgart: Klett-Cotta.

59. Sardari, M.; Rezayof, A.; Khodagholi, F. (2015). Hippocampal signaling pathways are involved in stressinduced impairment of memory formation in rats. In: Brain Research, Vol. 1625, 54-63.

60. Schachl, H. (1991). Lernen ohne Angst. Mehr Freude und Erfolg in der Schule. Wien: Bundesministerium für Unterricht und Kunst.

61. Schachl, H. (2010). What's in Our Head? Principles and Implications of Brain-Based Teaching and Learning. In: Petlak, E. et al.: Neuropedagogika a Vyucovanie. Nitra: KEGA 3/7007/09, 45-55.

62. Schachl, H. (2011). The Neuroscientific Approach to Learning. Old Wine in New Tubes? In: Kurincova, V., Seidler, P., Komora, J. (Hrsg.). Strategicky vycnam inovacii v edukacnej teorii a praxi. University Nitra: University Press.

63. Schachl, H. (2012). Was haben wir im Kopf? Grundlagen für gehirngerechtes Lehren und Lernen. 3. aktualisierte und überarbeitete Auflage. Linz: Veritas

64. Schachl, H. (2017). Neuroscience: A Traditional and Innovative Approach to Education with Focus on Stress with Learning. In: SIGNUM TEMPORIS. Band 8, Heft 1, Seiten 9-21, ISSN (Online) 1691-4929, DOI: https://doi.org/10.1515/sigtem-2016-0012, January 2017.

65. Schachl, H.; Kassymova, G. K. (2017). Innovative Approach to Education by considering of stress. In: In the world of EDUCATION, Nr. 6, 6.12.2017, 19-21.ISSN 2307-5287.

66. Seligman, M. E. P. (1979). Erlernte Hilflosigkeit. München, Wien, Baltimore: Urban und Schwarzenberg.

67. Sheldon, S.; Chu, S.; Nitschke, J. P.; Pruessner, J. C. \& Bartz, J. A. (2018). The dynamic interplay between acute psychosocial stress, emotion and autobiographical memory. In: Scientific Reports, volume 8, Article number 8684, 06 June 2018.

68. Simard, S.; Coppola, G.; Rudyk, C. A.; Hayley, S.; McQuaid, R. J. \& Salmaso, N. (2018). Profiling changes in cortical astroglial cells following chronic stress. In: Neuropsychopharmacology, volume 43, 1961-1971, 29. May 2018.

69. Sterley, T-L.; Baimoukhametova, D.; Füzesi, T.; Zurek, A. A.; Daviu, N.; Rasiah, N. P.; Rosenegger, D. \& Bains, J. S. (2018). Social transmission and buffering of synaptic changes after stress. In: Nature Neuroscience volume 21, 393-403, 08 January 2018.

70. Stuber, G. D.; Klanker, M.; de Ridder, B.; Bowers, M. S.; Joosten, R. N.; Feenstra, M. G. \& Bonci, A. (2008): Reward-predictive Cues enhance Excitatory Synaptic Strenght onto Midbrain Dopamine Neurons. In: Science, Vol 321, 19.9.2008, 1690-1692. 
71. Stuber, G. D.; Sparta, D. R.; Stamatakis, A. M.; van Leeuwen, W. A.; Hardjoprajitno, J. E.; Cho, S.; Tye, K. M.; Kempadoo, K. A.; Zhang, F.; Deisseroth, K. \& Bonci, A. (2011).Excitatory transmission from the amygdala to nucleus accumbens facilitates reward seeking. In: Nature, 21. July 2011, 377-380.

72. Sutherland, M. T.; Riedel M. C.; Flannery, J. S.; Yanes, J. A.; Fox, P. T.; Stein, E. A. \& Laird, A. R. (2016). Chronic cigarette smoking is linked with structural alterations in brain regions showing acute nicotinic drug-induced functional modulations. In: Behavioral and Brain Functions, doi: 10.1186/s/12993016-0100-5, 2. June.

73. Suwabe, K.; Hyodo, K.; Byun, K.; Ochi, G.; Fukuie, T.; Shimizu, T.; Kato, M.; Yassa, M. A.; \& Soya, H. (2017). Aerobic fitness associates with mnemonic discrimination as a mediator of physical activity effects: evidence for memory flexibility in young adults. In: Scientific Reports 7, doi: 10.1038/s41598-017-04850y, 11. July.

74. Suzuki, W.; Fitzpatrick, B. (2016). Fittes Gehirn, erfülltes Leben. München: Goldmann. English Version (2015): Healthy Brain, Happy Life. Verlag Dey Street.

75. Theill, N., Schumacher, V., Adelsberger, R., Martin, M., \& Jäncke, L. (2013). Effects of Simultaneously Performed Cognitive and Physical Traning in Older Adults. http://www.biomedcentral.com/14712202/14/103 (16.08.2015).

76. Vogel, S.; Schwabe, L. (2016). Learning and memory under stress: implications for the classroom. In: npj Science of Learning 1, doi: 10.1038/npjscilearn.2016.11, 29. June.

77. Vogel, S.; Kluen, L. M.; Fernandez, G. \& Schwabe, L. (2018). Stress affects the neural ensemble for integrating new information and prior knowledge. In: NeuroImage, Volume 173, 176-18, 7 June 2018.

78. Wang, M.; Gamo, N. J.; Yang, Y.; Jin, L. E.; Wang, X.-J.; Laubach, M.; Mazer, J. A.; Lee, D. \& and Arnsten, A. F. T. (2011). Neuronal basis of age-related working memory decline. In: Nature, 11. August 2011, 210-213.

79. Ward, N.; Paul, E.; Watson, P.; Cooke, G. E.; Hillman, C. H.; Cohen, N. J.; Kramer, A. F. \& Barbey, A. K. (2017). Enhanced Learning through Mulitmodal Training: Evidence from a Comprehensive Cognitive, Physical Fitness, and Neuroscience Intervention. DOI: 10.1038/s41598-017-06237-5.

80. Wolf, C. (2009). Flüchtige Erinnerung. In: Gehirn\&Geist, 4, 56-61.

81. Yerkes, R. M.; Dodson, J. D. (1908). The relation of strength of stimulus to rapidity of habit-formation. In: Journal of Comparative Neurology and Psychology, 18, 459-482.

82. Youssef, N. A.; Lockwood, L.; Su, S.; Hao, G. \& Rutten, B. P. F. (2018). The Effects of Trauma, with or without PTSD, on the Transgenerational DNA Methylation Alterations in Human Offsprings. In: Brain Sciences, 8, 83, 8. May 2018, https://www.ncbi.nlm.nih.gov/pmc/articles/PMC5977074/. 